УДК 130.2:379.85

Кунденко Я. М., Гаплевська О. I.

doi: 10.32620/gch.2019.1.07

\title{
ТУРИЗМ ЯК ДУХОВНА ПОДОРОЖ СУЧАСНОї ЛЮДИНИ
}

\author{
Статтю присвячено дослідженню туризму в осмисленні процесів сучасного духовного \\ життя людини й суспільства. \\ Ключові слова: духовне життя, ціннісні орієнтації, туризм.
}

The article is devoted to the study of tourism in understanding the processes of modern spiritual life of man and society.

Keywords: spiritual life, value orientations, tourism.

Статья посвящена исследованию туризма в осмыслении проиессов современной духовной жизни человека и общества.

Ключевые слова: духовная жизнь, ценностные ориентации, туризм.

Постановка проблеми. Важливою особливістю сфери духовності в сучасному інформаційному соціумі $\epsilon$ орієнтація на конкретну людину як екзистенціальну одиницю, що «переживає» у своєму потоці свідомості сутність світу, що постійно розвивається у взаємодії. Це породжує зміну в системі координат, основними напрямками якої є естетичні, етичні, гносеологічні цінності, що є підгрунтям для формування людини й суспільства. Людина неодноразово розглядалася як центр природи й культури, проте конкретність одиничної людини як аксіологічної цінності істотно видозмінює уявлення про прекрасне, високе й істинне. Ця зміна повністю знищує такі сфери класичної творчої діяльності, як мистецтво, релігія, наука й філософія.

Мистецтво, орієнтоване на художника, що створює твір мистецтва не як прекрасний і загальновизнаний ідеал, а як приємне й корисне для себе та глядача, переходить у самодіяльність і сферу споживання, що є не стільки некрасивим, скільки потворним і ницим, що принижує й знищує людину як духовну істоту. Однак при цьому не змінюється визначеність мистецтва як чуттєвої форми істини, що впливає на людину за допомогою образу, який у цьому поданні працює «від зворотного», показуючи, якими не повинні бути людина і світ, що руйнує їх єдність і взаємодію. Таким чином, мистецтво не знищується, а розвивається як світоглядна форма.

Щодо релігії, що постає як протилежність мистецтву й виробляє основні етичні ідеали для існування людини й суспільства, необхідно відзначити такі видозміни в уявленні про Бога й душу як ідеальну сутність світу та людини: висловлення Ніцше «про смерть Бога» та «владу Надлюдини» стають реальністю, сучасні релігійні вірування орієнтовані на конкретного «людино-бога» й духовні практики як езотеричне знання.

При цьому сфера раціонального знання виявляє його «відносність» і змістовну визначеність у діяльності дослідника. Через це змінюються предметна галузь i 
методика дослідження: реальність, що вивчається, набуває віртуального характеру, що призводить до тісної співпраці й успішної взаємодії природознавства та гуманітарного знання в синтетичних технічних науках. Крім того, суперечності сучасних релігійних рухів і наукових пошуків розв’язуються в межах «філософської віри», запропонованої К. Ясперсом як підстава для соціальної комунікації. У цьому випадку віра й знання змінюються розумінням як методологічним фундаментом сучасного наукового знання, а також основою для руйнування сумнівів щодо релігійних уявлень.

Сучасна філософія проходить етап трансформації і $є$ філософствуванням, що має міфологічний характер, який дозволяє створювати світоглядну «ризому» кожній людині, реальне втілення якої потребує нових колективних «ритуалів» у конкретності життєвого досвіду й у сфері дозвілля.

Актуальність теми дослідження зумовлюється тими об'єктивними процесами, що свідчать про якісні зміни в життєдіяльності сучасної людини. Це стосується, насамперед, зростання ролі такого соціопсихологічного явища, як туризм. На думку О. В. Головашенко, взаємозв'язок соціалізації людини й реалізації нею свого потенціалу в туристській активності стає наочним і безсумнівним. Крім того, зміни в змісті й характері праці під впливом глобалізації соціальних процесів і підвищення мобільності людини стимулюють розвиток туристичної індустрії. Туристська діяльність людини зумовлює розв'язання таких важливих соціальних завдань, як повноцінне відтворення людини як біосоціальної істоти в умовах монотонної праці й повсякденності, надання особистості нових емоційних та естетичних вражень i засвоєння нею передових форм соціального досвіду [5].

Туризм постає ефективним засобом масової потреби й широкої доступності культурних, зокрема, рекреативних цінностей як дієвого каналу та джерела збереження й пізнання духовної спадщини.

Активність особистості розуміється як здатність людини до свідомої діяльності, як міра цілеспрямованого перетворення нею навколишнього середовища й самої себе на основі засвоєння багатства матеріальної й духовної культури. Людина набуває духовні цінності для себе й для суспільства тільки тоді, коли вона стає активним учасником формування своєї особистості. Таким чином, духовні цінності чинять потужний вплив на життя кожної окремо взятої особистості. Ми не можемо жити ізольовано від суспільства, не беручи до уваги норми й порядки, що панують у ньому. Духовні цінності формують у нас моральні ідеали, народжують індивідуальні прагнення.

Саме в процесі особистого духовного життя кристалізується індивідуальний ціннісно-нормативний стрижень людини, розробляється програма власної життєдіяльності, розв'язується питання про сенс життя, усі психічні характеристики почуття, емоції, воля, уява, мислення - набувають ціннісної спрямованості й визначеності. Духовні цінності $\epsilon$ підгрунтям внутрішнього пошуку людини, іiі прагнень, формування світогляду, індивідуального погляду на навколишню дійсність.

Ступень наукової розробки проблеми. Серед науковців, які досліджують питання, пов'язані з ціннісною орієнтацією людини й процесом збагачення людини 
духовними смислами, є М. Бердяєв, Ю. Білодід, С. Кримський, Д. Леонтьев, Ю. Руденко, Т. Титаренко, К. Ясперс та ін.

Також слід зазначити науковців, праці яких досліджують туризм як соціокультурне явище, пошук самоідентифікації й засіб розширення людської свободи: це О. Бегей, Л. Божко, В. Буйленко, Л. Голянич, А. Галіздра, С. Соляник та ін. Так, Л .М. Голянич акцентує, що турист одночасно постає «приймачем світової культури» та «відтворювачем культури» певного соціуму [6].

Метою нашої статті $€$ характеристика духовно-практичної ціннісної орієнтації такої соціальної групи, як туристи, і дослідження туризму в осмисленні процесів сучасного духовного життя українців. Об'єктом дослідження $є$ туризм як інноваційний простір ціннісного обміну. Розкриваючи зміст поняття «турист», ми визначаємо його як суб'єкт ціннісної парадигми сучасного туризму.

Основна частина. Туризм як специфічна форма діяльності виник порівняно недавно, але коріння його сягають стародавніх часів. Уважається, що термін «туризм» увів французький письменник Анрі Стендаль (1783-1843) або, щонайменше, він популяризував його. Любителя подорожувати стали називати туристом десь наприкінці XIX ст. Запозичене з французької мови слово мало тоді дещо глузливий відтінок, наближаючись за значенням до «гультяя» та «волоцюги». Трохи пізніше настільний енциклопедичний словник витлумачив туризм як «подорож задля власної насолоди, розваги» [10].Туризм, або туристські поїздки, - це подорожі відвідувачів в іншу країну або місцевість, відмінну від місця постійного проживання, на термін менше року з будь-якою головною метою, крім працевлаштування.

Туризм - динамічне утворення, що формується й видозмінюється щодо ціннісноорієнтаційних потреб як суспільства загалом, так і окремої особистості. Виникнення нових цінностей і визначення їх мотивів спонукають до вчинкових дій, створюють той життєвий шлях, наявність якого й робить людину активним суб'єктом туризму. У дослідженні Т. М. Титаренко це положення розвинуте до дефініції: «Життєвий світ $\epsilon$ результатом саморуху, саморозвитку особистості, розгортання особистих цінностей i смислів та структурування відносно до них зовнішньої дійсності» [9].

Як зазначає В.Ф. Буйленко, на зміну індустріальній епосі, у якій основною цінністю був матеріальний добробут, приходить постіндустріальна епоха, де головною метою $є$ враження й відчуття. Важливими чинниками, що впливають на розвиток туризму, стали розвиток транспорту, зв'язку, зростала урбанізація, скорочення робочого часу, мобільність, зростання суспільного багатства. Сучасний туризм неможливий без діяльності 3 виробництва туристичного продукту: екскурсійних бюро, транспорту, готелів, спеціального одягу, спорядження й т. п.

Швидке посилення фінансово-економічних позицій туристської галузі призвело до того, що в багатьох країнах світу туризм став істотним чинником регіонального розвитку. Органи територіального управління різних ієрархічних рівнів піклуються про розвиток туризму й місцевостей, що мають цінні рекреаційні ресурси. Туризм розглядається як каталізатор регіональної економіки, що дозволяє задіяти не лише весь комплекс рекреаційних ресурсів, але й найбільш ефективним чином використати сукупний виробничий і соціально-культурний потенціал території за збереження 
екологічної й культурної різноманітності. Виходячи 3 цього, влада ініціює розроблення стратегії туристської активності, спільно 3 бізнесом - розроблення туристської інфраструктури, створення національних парків i рекреаційних зон, залучення інвестицій і зростання числа візитів у регіон [3].

Уплив на процеси національної ідентифікації й самоідентифікації подорожніх здійснюються через засоби масової комунікації: мережі Інтернет, телебачення, пресу тощо. Під час подорожі турист більше, ніж у повсякденному житті, керується емоціями й тому, як вважає О. І. Бегей, швидше засвоює нову інформацію, не поділяючи її на «наукову» й «міфічну» [1, с. 93].

Сучасні дослідники вважають, що сфері туризму притаманні властивості постмодернізму: домінування форми над змістом, стирання меж між реальністю й вигадкою. Туризм можна назвати засобом поєднання реального й ідеального: людина під час подорожі прагне вийти за межі звичайного життя, наблизитися до своєї мрії. Рушаючи в подорож, турист прагне отримати незабутні враження, побачити й відчути інше середовище, познайомитися з іншою культурою $[1 ; 2 ; 4 ; 5 ; 8]$.

Туризм, на думку А.С. Галіздри, виражає потребу сучасної людини у все зросталих темпах змінювати образи реальності, оскільки подорожі дозволяють отримати максимум образів за мінімальний період часу [4].

Духовна складова присутня в науковому, оздоровчому й спортивному туризмі, туристи активно беруть участь у культурних заходах: міжнародних конференціях, екскурсіях, театралізованих, музичних, танцювальних, художніх i музейних виставках, кінофестивалях, національних карнавалах тощо. Ось чому досить різноманітні можливості $\epsilon$ в туризму як засобу духовного збагачення. Сучасні дослідження свідчать, що ціннісні орієнтири туристів ще залежать від віку й туристичного досвіду. Молодь в усвідомленні фізичних і духовних цінностей туризму на перше місце ставить фізичне вдосконалення людини, а розширення духовних потенцій - на друге.

Ми, як і більшість дослідників, бачимо в туризмі ефективний і універсальний засіб виховання, що містить насамперед духовний, моральний, естетичний, а потім i фізичний вплив, адже здатність усвідомлювати, розуміти й відчувати прекрасне надають саме подорожі, знайомство 3 життям у всіх його проявах у всіх куточках планети [7].

Висновок. Духовне життя сучасного українського суспільства загалом зосереджене на розробленні нових ціннісних пріоритетів та особистісних експериментах за максимальних можливостей експериментування 3 різними соціальними ролями й просторовими переміщеннями в пошуках самоідентифікації.

Туризм якнайтісніше пов'язаний із культурним розвитком суспільства, його ціннісними пріоритетами й орієнтирами. Він $є$ значним соціальним процесом, важливість впливу якого до останнього часу не здавалася настільки очевидною. Поряд із мобільними технологіями сучасності туризм свідчить про перетворення практики комунікації в дію. Туризму в певному розумінні сприяє співіснуванню культур в індивідуальному досвіді людини, яка допускає готовність до взаємодії, прагнення до плюралізму, а не до однаковості. 
Взаємозбагачення транснаціональних форм загальнолюдської культури відбувається значною мірою завдяки обміну соціокультурною інформацією між туристами. Щодо цього туризм відіграє найважливішу роль культурної взаємодії, проте, як акцентує В. Зорин, «...деякі споживчі пріоритети сучасного суспільства ведуть до масових просторових практик туризму, нівелюють його одвічний когнітивний потенціал» [7].

Таким чином, як свідчать дослідники туризму, це явище суперечливе. Так, Л. Божко й А. Галіздра відзначають, що, з одного боку, туризм передбачає свободу пересування й вибору найцікавішого з усього різноманіття соціокультурного буття людства й можливість долучатися до нього. Із другого боку, глобальна туристська експансія ставить питання про загрозу видозміни орієнтирів ідентичності, найнебезпечнішим наслідком чого стає загроза втрати ідентичності, що тягне за собою ціннісну деструкцію, неузгодженість цінностей, конструювання штучної ідентичності на підставі соціальних стереотипів феномена туризму[2; 4].

Загалом, сучасний туризм маркує процес створення культури, постає модифікатором соціокультурних змін в аксіосфері, убираючи в механізм функціонування такі характеристики соціокультурної реальності, як мобільність, віртуальність, візуальність, акцентування споживчих пріоритетів. Крім того, сучасний турист подібний Сталкеру з фільму А. Тарковського, що «подорожує» Зоною, де його чекає кімната, у якій виконується його основне бажання - зрозуміти свою сутність $\mathrm{i}$ призначення.

\section{Література:}

1. Бегей O. I. Міфотворчість як фактор розвитку сучасного туризму // Інтелект. Особистість. Цивілізація. Донецьк : ДонНУЕТ, 2011. Вип. 9. С. 92-96.

2. Божко Л. Д. Проблеми інтерпретації туризму як феномена масової культури: друга половина XX - початок XXI ст. //Вісник Національної академії керівних кадрів культури і мистецтв, 2013. №2. C. $176-181$.

3. Буйленко В. Ф. Туризм. Ростов-на-Дону : Феникс, 2008. 411 с.

4. Гализдра A.C. Феномен туризма в пространствемассовойкультуры.Саратов, 2006. URL : http ://tourlib.net/statti_tourism/galizdra.htm (дата звернення 15. 01. 2019).

5. Головашенко O. B. Соціально-філософський аналіз туризму та його мотивації // Гуманітарний вісник Запорізької державної інженерної академії. Запоріжжя : Видавництво ЗДІА, 2001. Вип. 6. C. 29-33.

6. Голянич Л. М. Ціннісний зміст сучасного туризму // Науковий вісникУжНУ,2009. Серія «Економіка». Вип. 28. С. 19-21.

7. Зорин И. В. Аксиологическое пространство как предметная область педагогики туризма // Теория и практика физической культуры, 2000. №8. URL : http ://lib.sportedu.ru/Press/tpfk/2000N8/p2326.htm (дата звернення 15. 01. 2019).

8. Соляник С. Ф. Сучасний культурний міф у контексті комунікативної концепції туризму. URL : http://www.newacropolis.org./ua/study/conference/?thesis=3705 (дата звернення 15. 01. 2019).

9. Титаренко Т. М. Життєвий світ особистості: структурно-генетичний підхід : автореф. дис. д. псих. наук: 10.00.01 КДУ ім. Т. Шевченка. Київ, 1994. 48 с. 
10. Туризм як сучасний спосіб духовного розвитку та збагачення. URL : http ://uastudent.com/turyzm-jak-suchasnyj-sposib-duhovnogo-rozvytku-ta-zbagachennja/ （дата звернення 15. 01.2019).

\section{References:}

1. Begey O.I. Mifotvorchistyakfaktorrozvitkusuchasnogoturizmu[Mythcreation as a factor in the development of modern tourism]. //Intelekt. OsobistIst. Tsivilizatsiya. Donetsk : DonNUET. 2011. Vip. 9. P.92-96.

2. Bozhko L. D. Problemi Interpretatsiнi turizmu yak fenomenamasovorikulturi: drugapolovina XXpochatok XXI st.[Problemsofinterpretationoftourismas a phenomenonofmassculture: thesecondhalfofthe XX - thebeginningofthe XXI century]. I/VisnikNatsionalnoнiakademiymikerivnihkadriv kulturiimistetstv, 2013. №2.P. 176-181.

3. Buylenko V. F. Turizm [Tourism]. RostovnaDony: Feniks, 2008. 411 p.

4. Galizdra A. $\quad S$. Fenomenturizma vprostranstvemassovoykulturyi[Thephenomenonoftourisminthespaceofmassculture].Saratov, 2006.

5. Golovashenko $\quad$ O. $\quad$ V. $\quad$ Sotsialno-filosofskiyanaliz turizmutayogomotivatsiyi[Sociophilosophicalanalysisof tourism and its motivation].// Gumanitarniy visnikZaporizkoyi derzhavnoyi inzhenernoyi akademiyi.Zaporizhzhya : Vidavnitstvo ZDIA,Vip. 6.2001. P. 29-33.

6. Golyanich L. M. Tsinnisniyzmistsuchasnogoturizmu[Valuablecontentofmoderntourism]// Naukoviy visnikuzhnu, 2009. Seriya «Ekonomika». Vip. 28. P. 19-21.

7. Zorin,

Aksiologicheskoeprostranstvokakpredmetnayaoblastpedagogikiturizma[Axiologicalspaceas

I. $V$. subjectareaoftourismpedagogy] // Teoriyaipraktikafizicheskoykulturyi,2000. №8.

8. Solyanik S.F. Suchasniykulturniy mif u kontekstikomunikativnoyi kontseptsiyi turizmu[Modernculturalmythinthecontextofthecommunicativeconceptoftourism].

9. Titarenko T. M. Zhitteviysvit osobistosti: strukturno-genetichniy pidhid[Thevitalworld of personality: structural-genetic approach]. : Avtoref. dis. dokt. psihol. Nauk: 10.00.01 KDU Im.T.Shevchenka. Kiiv, 1994. 48 p.

10. Turizmyaksuchasniysposib duhovnogorozvitkutazbagachennya[Tourismas a modern way of spiritual development and enrichment].

\section{Yana Kundenko, Olga Gaplevska}

\section{TOURISM AS SPIRITUAL TRAVEL OF MODERN HUMAN}

The article is devoted to the study of tourism in understanding the processes of modern spiritual life of man and society.

The purpose of our article is to characterize the spiritual and practical value orientation of such a social group as tourists, and the study of tourism in understanding the processes of modern spiritual life of Ukrainians. The object of the research is tourism as an innovative space of value exchange. Expanding the meaning of the concept of «tourist» we define it as a subject of value paradigm of modern tourism.

Tourism is a dynamic entity that is formed and changed in relation to the valueorientation needs of both society as a whole and an individual as a whole. The emergence of new values and the recognition of their motives, inducing action, create the life path, the presence of which makes a person an active subject of tourism. 
In general, modern tourism marks the process of creating a culture. It serves as a modifier of socio-cultural changes in the axisosphere, absorbing in the mechanism of functioning such characteristics of socio-cultural reality as mobility, virtuality, visibility, and accentuation of consumer priorities. In addition, the modern tourist is similar to Stalker from the film by A. Tarkovsky, who «travels» to the Zone, where he is awaited by a room, in which his main desire to understand his essence and purpose is fulfilled.

Keywords: spiritual life, value orientations, tourism.

\section{Яна Кунденко, Ольга Гаплевська}

\section{ТУРИЗМ ЯК ДУХОВНА ПОДОРОЖ СУЧАСНОЇ ЛЮДИНИ}

Статтю присвячено дослідженню туризму в осмисленні процесів сучасного духовного життя людини й суспільства.

Метою статті є характеристика духовно-практичної ціннісної орієнтації такої соціальної групи, як туристи, і дослідження туризму в осмисленні процесів сучасного духовного життя українців. Об'єктом дослідження є туризм як інноваційний простір ціннісного обміну. Розкриваючи поняття «турист», визначено його зміст як суб'єкта ціннісної парадигми сучасного туризму.

Туризм - динамічне утворення, що формується й видозмінюється щодо ціннісноорієнтаційних потреб як суспільства загалом, так і окремої особистості. Виникнення нових цінностей i визнання їх мотивацій, що спонукають до вчинкових дій, створюють той життєвий шлях, наявність якого й робить людину активним суб'єктом туризму.

Загалом сучасний туризм маркує процес творення культури, постає модифікатором соціокультурних змін в аксіосфері, убираючи в механізм функціонування такі характеристики соціокультурної реальності, як мобільність, віртуальність, візуальність, акцентування споживчих пріоритетів. Крім того, сучасний турист подібний Сталкеру з фільму А. Тарковського, що «подорожує» Зоною, де на нього чекає кімната, у якій виконується його основне бажання - зрозуміти свою сутність і призначення.

Ключові слова: духовне життя, цуіннісні орієнтації, туризм.

KundenkoYana - Candidate of Philosophy, Associate Professor, Associate Professor of the Department of Social and Human Sciences Kharkiv National University of Construction and Architecture.

Кунденко Яна - кандидат філософських наук, доцент, доцент кафедри суспільно-гуманітарних дисциплін Харківського Національного університету будівництва і архітектури.

e-mail: kundenkoyana@gmail.com 
Gaplevska Olga - Head of the Laboratory of the Department of Philosophy of the National Aerospace University «Kharkiv Aviation Institute».

Гаплевська Ольга - завідувач лабораторією кафедри філософії Національного аерокосмічного університету ім. М. С. Жуковського «Харківський авіаційний інститут».

e-mail: ogaplevska@gmail.com

...Дуже вдячна долі, яка постійно надає можливість співпрачювати з моїми колегами та друзями з кафедри філософії XАI, де відбулися основні події мого наукового й особистісного становлення. Маю надію ще довго та успішно спілкуватися з ними.

Кунденко Яна - кандидат філософських наук, доцент, працювала на кафедрі філософії ХАI з 1991 до 2006 рр. Була аспірантом кафедри.

...Від студентки факультету літакобудування до завідувача лабораторією кафедри філософії - ось мій професійний шлях у XАI. На початку 2000-х рр. ми, аспіранти кафедри філософії без базових фахових дипломів: Кунденко Яна, Гордієнко-Митрофанова Ія, Чернієнко Володимир, Більчук Наталя, Плахотнік Ольга, Свящук Андрій сперечалися й відстоювали свої погляди й прагнення, нині вони кандидати, а дехто - доктори наук, завідувачі кафедр. 3 Яною Кунденко нас об'єднують спільні погляди на стосунки між людьми, їх духовно-практичне обтрунтування, тому останнім часом ми співпраџюємо, публікуємо тези, статті.

На кафедрі є картина аспіранта Титова Микити з зображенням філософії у вигляді жінки, яка блукає в темряві, осяяна світлом розуму. Вона одночасно рухлива й не рухлива, що символізує універсальність $і$ вічність ї̈ ідей, а також потяг до пізнання нового. Мандрівники як промінчики світла в темряві вічності. Так $і$ для мене, vрешті-решт, $v$ філософії, $v$ «любові до мудрості» проявляється прагнення до иілісності й набуття світу в усьому його багатстві.

Моя подяка всім, із ким мене звела доля на шляху мого становлення на кафедрі філософії. Моєю першою викладачкою з філософії бүла й залишається Ковалевська Ольга Вікторівна. Вона продовжує викладати студентам і аспірантам, любить життя, мандруе світом, пише віриі, уважає кафедру другою сім'єю. Тому бажаю, шоб назва ї̈ поетичної збірки стала епіграфом до намої з Яною статті: «Я путешествовать люблю, Чужсие страны рада видеть. Сейчас читателю дарю Все впечатленья...»

Гаплевська Ольга працювала на кафедрі філософії ще студенткою з 1982 р. до 1983 р., потім із 1989 р. на посаді лаборанта кафедри, зараз вона завідувач лабораторії кафедри філософії.

Надійшла до редакції 28.02.2019. Розглянута на редколегії 18.03.2019.

\section{Рецензенти:}

Доктор філософських наук, професор, професор кафедри суспільно-гуманітарних дисциплін Харківського Національного університету будівництва та архітектури Проценко О.П.

Доктор філософських наук, професор XAI, професор кафедри філософії Національного аерокосмічного університету ім. М. Є. Жуковського «ХАІ» Кузнецов А.Ю. 